meticulous matching of central and research council support for academic research is less important than opportunities for diversity. Earmarking is a poor cause.

But that will mean that less is spent on academic research. That will be the quick objection. In reality, however, it need not be like that. For one thing, the proportion of grants committee funds at present notionally devoted to research support is an uncertain figure, dependent on how academics choose to spend their time. The cash component of it is only small (but there is a case for letting universities compete for the annual equipment grant, in round figures about $£ 100$ million a year, on the basis of demonstrated need). If self-governing universities choose to spend less of their time on scholarship and more on teaching, this element of the dual-support system for research will vanish in any case. But will that not mean that some universities opt out of research as an integral part of academic life? Perhaps, but institutions cannot rigidly condition how academics spend their time and energy, and Britain is geographically well-shaped (with universities often cheek-by-jowl) for people to pursue their scholarship outside the walls of the institutions that employ them. Indeed, a further erosion of the dual-support system along these lines would only encourage a degree of mobility among academics (once the most mobile of all professional people) sadly absent in the past few years. And to make up for what may at first sight seem to be an undermining of the research enterprise, there is at least a chance that British universities will benefit from the coming reorganization of the research council establishments.

These are the simple questions in the grants committee questionnaire. The British system of higher education includes two kinds of institutions, universities and (as university academics like to think) the rest, mostly institutions called polytechnics. Such admissions statistics as there are suggest that universities have the first claim on young people's interest and that a polytechnic education is chiefly sought either by those to whom university entrance seems unattainable or those who have failed to enter a university. But this is only half the truth. Many of these institutions have academic departments as strong as or even stronger than corresponding departments in universities. And all of them have powerful political support (and municipal loyalty) from local authorities.

So what should be done about the great divide between the universities and the rest of the binary system? Why not simply abolish it? For if the outcome of the latest upheaval in the university system is more diversity and more incentives thereto, the notion that there should be two quite separate parts of the higher education system will become even more absurd than it is at present. And while the problem of simplifying the system as it stands by, for example, merging institutions of the two kinds is always likely to be impeded by academic snobbery and suspicion, the difficulties of merging the rules under which the two kinds of institutions coexist and compete with each other are surely much less formidable. Whether the polytechnics would in present circumstances welcome the chance to be called universities is another matter, while there would be legal difficulties in arranging that those with a consistent academic record should be allowed to award their own degrees. But there seems no point in looking for ways of bridging this snobbish division in British higher education when it is far simpler to get rid of it. That is what the government should be pushing for.

\section{Who knows science?}

\section{The Royal Society Committee studying public understanding should not blame the press.}

Do people in general have a sufficient understanding of what science is about and, if not, what can be done to help them? This, improbable as it may seem, is one of the questions the Royal Society (of London) has set out to answer. In reality, the question has not popped up out of the blue, but has been indirectly wished on the society by developments elsewhere, for example by another of the Royal Society's committees (on education) last year and then, more recently, by the British Government's declaration of interest at the Williamsburg summit in an international programme in scientific understanding. The Royal Society is wise to plan ahead, and to be prepared for the inevitable occasion that will arise when the government turns to it for help with a curious commitment undertaken without much forethought in the heady preparation for Williamsburg. In any case, the committee that will carry out the study (whose chairman is Dr Walter Bodmer, director of the Imperial Cancer Research Fund's laboratories) is a level-headed group, and will no doubt have useful things to say. The danger, as always, is that it will spend its time looking in the wrong places for explanations of irrelevant phenomena.

Very little prescience will be needed to conclude that the public understanding of science (which term must be taken to include technology) is appalling, and probably worse in Britain than elsewhere. One fashionable explanation (in Britain) is that the newspapers serve science badly, which is probably true, and one frequently suggested remedy is that newspapers should be urged (or encouraged) to change their ways, which overlooks the simple truth that the British press is a free press, that the commercial environment in which it survives (sometimes, only just) provides every incentive to give readers what they are likely to want and that the common complaints against the newspapers (not merely for their inadequate treatment of science but for sensationalism, invasions of privacy and the like) mistake symptoms for causes. It is as good a working hypothesis as any other that the treatment of science in the British press is less than satisfactory because readers fail to ask for better. Moreover (as UNESCO - the United Nations Educational, Scientific and Cultural Organization - in another connection is finding to its cost), to seek even by indirect pressure to make a free press behave differently is to put its freedom in hazard. Exhortation and encouragement are, of course, a different matter.

So where else should the Bodmer committee look for a point at which remedies might be applied? It could do worse than begin with the British educational system, and at the secondary schools in particular. But what can be wrong there? Is not the British school system renowned throughout the world for its skill at teaching more specialized science to more students at a more tender age than in any other comparable community? Those who doubt the truth of this claim should look at the examination papers offered to British school-leavers competing for places at British universities (see p.219). The other side of that coin, of course, is that equal numbers of young people emerge from their school careers with an equally specialized knowledge of some quite different field, Latin and Greek for example, and with only a smattering of science gleaned from some early experience of some specialized science course. The plain truth is that in Britain from the age of thirteen hardly anybody is offered help in coming to grips with science in general. Even the courses offered to people aged 13-16 under the headings of "physics", "chemistry" and so on are more like preparations for the more rigorous specializations of the school-leaving examinations than educational experiences in their own right. Moreover, British universities (with one exception) provide no relief from these trammelled educational careers. Is it any wonder that most scientists in Britain end up with few skills outside their own special fields but with a resentment that those who administer their affairs (such as far too many civil servants) are ignorant of what laboratories are for?

But, the Bodmer committee will protest, how can it be possible to advocate a radical reform of British secondary education (and of university admissions procedures as well) at a time like this, when there is no money to spare? The climate may, however, be more favourable than it appears. The British Government has for some time been preaching the importance of a core curriculum for secondary schools, and seems to have been making headway. And when higher education is (yet again) in a state of flux (see above), the right word from a potentially influential committee such as Bodmer's might persuade some of them that the time has come to give up their insistence on school specialization. Certainly no harm can come from telling the truth. 